\title{
Clinicogenetics of Parkinson's disease: a drawing but not completed picture
}

\author{
Chao-Dong Wang ${ }^{1}$, Piu Chan ${ }^{2}$ \\ ${ }^{1}$ Department of Neurology, The Affiliated Sanming First Hospital, Fujian Medical University, Sanming 365000, Fujian, China. \\ ${ }^{2}$ Department of Neurobiology and Neurology, Key Laboratory for Neurodegenerative Diseases of Ministry of Education, Xuanwu \\ Hospital of Capital Medical University, Beijing 100053, China.
}

\section{A B S T R A C T}

Parkinson's disease (PD) is a prevalent neurodegenerative disorder mainly affecting the population over the age of 60 years. The past decade has seen rapidly emerging data supporting a major importance of genetic factors in the development of PD. Increasing number of large-scale and replicating association studies has facilitated the confirmation of the possible predisposing factors to PD and the selection of genetic variants for risk prediction. While evidences are accumulating that variations within the SNCA, LRRK2, MAPT and GBA genes increase the individuals' vulnerability to PD, inconclusive or negative results have been reported for an association between PD and variants of the parkin, PINK1, DJ-1, UCH-L1, Omi/HtrA2, GIGYF2, PLA2G6, VPS35, EIF4G1 and BST1 genes. However, our understanding of the genetic picture of PD remains preliminary. Molecular diagnosis of the disease is only recommended for cases with clear family history, and currently, there is no ideal genomic biomarker available to predict the disease onset and progression, or to make a molecular classification of the disease. Efforts are expected to identify more genetic predisposing factors and to further clarify their roles in the mechanisms of PD.

Key words: Association, biomarkers, genetic variants, Parkinson's disease

\section{INTRODUCTION}

Parkinson's disease (PD) is a prevalent neurodegenerative disorder affecting $1-2 \%$ of the population over the age of 60 years. ${ }^{[1]}$ The disease results mainly from progressive and profound degeneration of dopaminergic neurons in the substantia nigra with the presence of Lewy bodies containing aggregates of $\alpha$-synuclein and other substances. ${ }^{[2,3]}$ Although the etiology and mechanisms of PD remain largely unclear, the development of the disease is believed to be the combined results of three interactive events: genetic susceptibility, environmental exposures and the aging process. ${ }^{[4-8]}$ The relative role of genetic and environmental factors has been debated for many years, however, evidences are rapidly accumulating that genetic risk factors are of major importance in the sporadic form of the disease, accounting for at least 10\% of the general PD population. ${ }^{[1,9-11]}$

\begin{tabular}{|l|l|}
\hline \multicolumn{2}{|c|}{ Access this article online } \\
\hline Quick Response Code: & \\
\hline & Website: \\
\hline & www.nnjournal.net \\
& DOI: \\
\hline
\end{tabular}

One important conceptual update of the genetic profiling of $\mathrm{PD}$ is that mutations or variations within causative genes for a minority of monogenic familial PD are also associated with sporadic PD. Studies in PD families have identified 11 (a-synuclein, parkin, UCH-L1, PINK1, DJ-1, LRRK2, ATP13A2, OMI/HTRA2, FBX07, VPS35, EIF4G1) causative genes and 4 loci of linkage across the genome (PARK3, PARK10, PARK12 and PARK16) pending characterization. Analysis of mutations or variations in many of these genes has been performed in recent years among diverse ethnic populations. In addition, the newly emerged genome-wide association studies (GWAS) have been used to identify novel genetic associations with the disease at the whole-genome level. ${ }^{[12-15]}$ More recent progress has been made by the powerful technique of next-generation sequencing. ${ }^{[16,17]}$ Further, more and more large-scale and multi-center collaborative analyses have been completed thanks to the improving analytic tools and the increasingly close international cooperation. The results published so far are consistent or conflicting with each other, reflecting confirmative, inconclusive or negative associations between genetic variants and PD. In this review, we give an up-to-date view of the genes that may have associations with the risk for PD and their implications in clinical

Corresponding Author: Dr. Chao-Dong Wang, Department of Neurology, The Affiliated Sanming First Hospital, Fujian Medical University, Dongxin $1^{\text {st }}$ Road, Liedong Street, Sanming 365000, Fujian, China. E-mail: cdongwang01@126.com 
practice, with emphasis on large-scale and multiethnic evidences, as listed in Table 1.

\section{GENETIC VARIATIONS WITH WELL-EVIDENCED ASSOCIATIONS WITH PARKINSON'S DISEASE}

\section{SNCA}

Genetic variability within the SNCA gene encoding $\alpha$-synuclein is arguably the most reliable association of a common genetic risk factor with PD identified to date. Although mutations in this gene account for $<1 \%$ of PD in the general population, abnormal aggregation of the SNCA-encoding protein, $\alpha$-synuclein, the principal component of Lewy bodies, is present in all patients with idiopathic PD. ${ }^{[16]}$ In addition, association studies have repeatedly suggested the link of the SNCA variations to both familial and sporadic PD. Further, several most recently completed GWAS consistently showed strong linkage of the SNCA locus to PD across Western and Oriental populations. ${ }^{[12-15]}$

Although three missense mutations in SNCA were reported in families with PD inheritance ${ }^{[18-20]}$ and thought to increase the aggregation of SNCA protein, point mutations have not been identified in sporadic $\mathrm{PD},{ }^{[21,22]}$ and no several nonsynonymous (SNPs) have been found in the coding region, suggesting that disease-related amino acid changes in SNCA are unlikely in sporadic PD. ${ }^{[23]}$ In contrast, multiplication, in particular triplication, of SNCA was revealed in both familial ${ }^{[24-29]}$ and sporadic PD cases. ${ }^{[30]}$ Due to the absence of point mutations in any of the copies of
SNCA in these patients, the cause of PD appears to be the mere increase in $\alpha$-synuclein levels. In support of this dosage effect, PD patients from families with two extra copies of SNCA have a more severe phenotype than PD patients with only one extra copy, ${ }^{[25,27,31]}$ and SNCA mRNA levels in the brain from sporadic patients are increased..$^{[2-35]}$

The pathogenicity of multiple SNCA gene copies and the apparent dosage effect of $\alpha$-synuclein levels in both sporadic and familial PD highlight the clinical significance of the regulation of SNCA gene expression, which can take place at both transcriptional and posttranscriptional levels. Transcription of genes is mainly regulated by the promoter sequence. The first promoter variant reported in association with PD was the mixed dinucleotide repeat sequence (REP1), which resides approximately $10 \mathrm{~kb} 5^{\prime}$ to the translation start site of SNCA. Despite some negative results of association, the majority of individual studies ${ }^{[36-39]}$ and a meta-analysis of data ${ }^{[40]}$ from 18 sites across multiple ethnic populations have confirmed an association between risk for PD and the longer REP allele. In addition, variants other than REP1 in the promoter region, such as SNPs flanking the core promoter at the -770 and -116 positions, rs2583988, rs2619364, and rs2619363, were also reported to increase the susceptibility to PD in European population. ${ }^{[41]}$ Posttranscriptional regulation of gene expression can be mediated by several elements, many of which are located in the 3'-untranslated region of mRNAs. ${ }^{[22,43]} \mathrm{A}$ series of studies reported an association of polymorphisms at the 3'-end of

Table I: Genes and loci related to Parkinson's disease

\begin{tabular}{|c|c|c|c|c|c|c|}
\hline Locus & Gene & Chromosome & Inheritance & Type of parkinsonism & $\begin{array}{l}\text { Mutation/varaint } \\
\text { type }\end{array}$ & Association with PD \\
\hline PARK1/PARK4 & SNCA & $4 q 21$ & $A D$ & LOPD/EOPD, dementia & Multiplication, point & Convinced \\
\hline PARK2 & Parkin & $6 q 25-27$ & $A R$ & EOPD & Re-arrangement, point & $\begin{array}{l}\text { Re-arrangement: convinced; } \\
\text { point: unconvinced }\end{array}$ \\
\hline PARK3 & Unknown & $2 p 13$ & $A D$ & LOPD & Point & Unconvinced \\
\hline PARK5 & UCHL1 & $4 \mathrm{p} 14$ & $A D$ & LOPD & Deletion, point & Unconvinced \\
\hline PARK6 & PINK1 & $1 p 36$ & $A R$ & EOPD & Deletion, point & Unconvinced \\
\hline PARK7 & DJ-1 & $1 p 36$ & $A R$ & EOPD & Deletion, point & Unconvinced \\
\hline PARK8 & LRRK2 & $12 q 12$ & $A D$ & LOPD & Point & Convinced \\
\hline PARK9 & ATP13A2 & $1 p 36$ & $\mathrm{AR}$ & $\begin{array}{l}\text { EOPD, Kufor-Rakeb } \\
\text { syndrome }\end{array}$ & Point & Unconvinced \\
\hline PARK10 & Unknown & $1 \mathrm{p} 32$ & Unknown & LOPD & Point & Unconvinced \\
\hline PARK11 & GIGYF2 & $2 q 37$ & $A D$ & LOPD & Point & Unconvinced \\
\hline PARK12 & Unknown & $x q 21-25$ & X-linked & LOPD & Point & Unconvinced \\
\hline PARK13 & HTRA2 & $2 p 12$ & $A D$ & LOPD & Point & Unconvinced \\
\hline PARK14 & PLA2G6 & $22 q 13$ & AR & $\begin{array}{l}\text { EOPD, } \\
\text { dystonia-parkinsonism }\end{array}$ & Point & Unconvinced \\
\hline PARK15 & FOXB7 & $22 q 12-13$ & $\mathrm{AR}$ & $\begin{array}{l}\text { EOPD, pallido- } \\
\text { pyramidal syndrome }\end{array}$ & Point & Unconvinced \\
\hline PARK16 & Unknown & $1 q 32$ & Risk & LOPD & Point & Unconvinced \\
\hline PARK17 & VPS35 & $16 q 11$ & Risk & LOPD & Point & Unconvinced \\
\hline PARK18 & EIF4G1 & $3 q 27$ & Risk & LOPD & Point & Unconvinced \\
\hline- & $G B A$ & $1 q 21$ & Risk & LOPD & Point & Convinced \\
\hline- & BST1 & $4 p 15$ & Risk & LOPD & Point & Unconvinced \\
\hline- & MAPT & $17 q 21$ & Risk & LOPD & Haplotype & Convinced \\
\hline- & ATXN2 & $12 q 12$ & Risk & LOPD & Trinucleotide expansion & Unconvinced \\
\hline- & ATXN3 & $14 q 32$ & Risk & LOPD & Trinucleotide expansion & Unconvinced \\
\hline
\end{tabular}


SNCA (e.g. rs356165 and rs356219) with sporadic PD, especially those from Southern Germany and Asian. ${ }^{[44-47]}$ Although molecular details are not clear, the 3 '-variants have been shown to increase the expression of $\alpha$-synuclein. ${ }^{[48]}$

\section{LRRK2}

The discovery of mutations in the LRRK2 gene as the cause of PD in the families linked to the PARK8 locus (12q12) was probably the most important step forward since the $\alpha$-synuclein discovery. ${ }^{[49,50]}$ LRRK2 is a very large gene that contains 51 exons, and over 30 sequence variants have been linked to autosomal-dominant Parkinsonism. However, only five (R1441C, R1441G, Y1699C, G2019S, and I2020T) have been shown or be clearly pathogenic, and two substitutions (G2385R, R1628P) have been associated with an increased risk for sporadic PD.

The most common LRRK2 mutation is Gly2019Ser. It is detected in about $5 \%$ of familial and 1-2\% of sporadic European PD patients ${ }^{[51,52]}$ and up to $30 \%$ of patients with PD from North African and 10-40\% of Middle Eastern populations. ${ }^{[53-56]}$ One intriguing feature of this mutation is its association with both familial and sporadic PD. However, the penetrance of this mutation is relatively low. By analyzing the pooled data of 24 populations worldwide (including 19,376 unrelated patients with PD), the International LRRK2 Consortium reported the risk of PD for a person who inherits the LRRK2 G2019S mutation was 28\% at age 59 years, 51\% at 69 years and $74 \%$ at 79 years. Although motor and nonmotor symptoms of LRRK2-associated PD were more benign than those of idiopathic PD, the core features (asymmetrical, tremor predominant parkinsonism with bradykinesia and rigidity that responded to dopamine) of the patients with LRRK2 G2019S-associated PD are indistinguishable from patients with idiopathic PD, again implying a critical contribution of LRRK2 to the PD pathogenesis. ${ }^{[57]}$

Although the G2019S is prevalent in PD patients in the above-mentioned populations, it does not occur at appreciable frequency in control cohorts from these populations and is strikingly rare in Chinese ${ }^{[58,59]}$ and South African. ${ }^{[60]}$ Therefore, it is more a population-specific mutation than a popular susceptibility variant. In contrast, two variants reported from Asian populations appear to be true risk variants for PD. The first G2385R was initially described in a Taiwanese family. ${ }^{[61]}$ Assessment of this variant in large Asian populations showed association with risk for disease in Taiwanese, Japanese, Hong Kong Chinese and mainland Chinese populations. ${ }^{[61-63]}$ In general this variant is present in about $10 \%$ of PD populations and
0.5-5\% in controls and confers at least two-fold risk for the chance of PD. Given that this association appears robust across Asian populations, this risk allele is an underlying factor in a very large number of PD cases worldwide. More recently a second LRRK2 risk allele, also identified within Asian PD populations has been described. ${ }^{[64,65]}$

\section{Microtubule associated protein tau}

The microtubule associated protein tau (MAPT) gene encodes MAPT. Tau modulates the assembly, dynamic behavior, and spatial organization of microtubules, and is a major protein component of neurofibrillary tangles, a hallmark lesion of Alzheimer's disease (AD). Mutations in the MAPT gene were identified to cause autosomal dominant frontotemporal dementia with parkinsonism linked to chromosome $17 .{ }^{[66]}$ In addition to rare causal mutations, common variability in MAPT has been linked to disease such as progressive supranuclear palsy, $\mathrm{AD}$ and $\mathrm{PD}$. The most frequently reported variation is caused by a common genomic inversion within a large block (approximately 1.6 Mb in length) containing the MAPT locus that shows reduced recombination and high levels of linkage disequilibrium. This phenomenon results in two common Caucasian haplotype groups across this locus, often termed $\mathrm{H} 1$ and H2. Association between MAPT H1 and risk for PD has been tested by many groups, ${ }^{[67,68]}$ and the results in general show a consistent association with the disease. Moreover, patients carrying the $\mathrm{H} 1$ allele present in their fifth decade either with behavioral/cognitive changes or with rapidly progressive and poorly levodopa-responsive parkinsonism. A recent follow-up study demonstrated that $17 \%$ of incident PD patients developed dementia over 5 years, and the MAPT H1/H1 genotype was an independent predictor of dementia risk (odds ratio $=12.1$ ). ${ }^{[69]}$ The results also suggested that Lewy body deposition in posterior cortical areas, which is influenced by MAPT genotype and the aging process are associated with subsequent global cognitive decline and dementia. However, the $\mathrm{H} 1$ haplotype may not be a universal risk allele because the $\mathrm{H} 2$ haplotype is almost exclusively Caucasian in origin, and its prevalence in other populations is essentially zero. $^{[70]}$

In addition to the $\mathrm{H} 1$ haplotype, a subhaplotype within the H1 clade composed of two "H1-SNPs" (rs242562 and rs2435207) spanning MAPT exons 1-4 was also significantly overrepresented in cases versus control subjects. ${ }^{[71,72]}$ However, except for in one Greek and one Nowegian study, the association of H1-subhaplotype with PD was not well replicated in other Caucasian studies, and Taiwan Chinese, ${ }^{[68,73,74]}$ and it has not been tested whether this subhaplotype is associated with PD in populations that possess merely the H1 clade. 
Glucocerebrosidase

The glucocerebrosidase (GBA) gene encoding a lysosomal enzyme called glucocerebrosidase that hydrolyses the beta-glycosidic linkage of glucosylceramide, a ubiquitous sphingolipid present in the plasma membrane of mammalian cells. ${ }^{[75]}$ Over 200 mutations have been described in GBA, including point mutations, deletions and recombination alleles derived from the pseudogene sequence. ${ }^{[76]}$ These mutations usually cause a recessive lysosomal storage disorder - Gaucher disease (GD), which is characterized by macrophages enlarged with deposits of glucosylceramide.

The initial recognition of an association between PD and GBA mutations came from the clinical observations of parkinsonian manifestations in genotypically heterogeneous patients with GD. ${ }^{[77]}$ Moreover, brain samples from autopsy-confirmed PD cases revealed significantly higher carrier frequencies (14\%) than the estimated GBA mutation carrier frequency in the general population (0\%). ${ }^{[78]}$ The frequency and distribution of GBA mutations in PD vary among populations. Ashkenazi Jewish PD patients have the highest carrier frequency with a range 13.7-31.3\%, compared with $4.5-6.2 \%$ in controls. ${ }^{[79,80]}$ It was lower in nonAshkenazi-Jewish populations, ranging 2.8-12\%, compared with $0.2-5.3 \%$ controls from the same populations. ${ }^{[81-83]}$ Among all the mutations, L444P and N370S turned out to be the most frequently identified in PD patients. Although N370S is also common in European populations, it has not been encountered among Asians. ${ }^{[84]}$ In contrast, L444P was believed as a panethnic mutation associated with PD. ${ }^{[85,86]} \mathrm{A}$ most recent multi-center study including 5691 patients and 4898 controls from 16 centers revealed that either mutation was found in $15 \%$ of patients and $3 \%$ of controls among Ashkenazi Jewish subjects, and in 3\% of patients versus $1 \%$ of controls among nonAshkenazi Jewish subjects. ${ }^{[87]}$ The odds ratio for any GBA mutation in patient's versus controls was 5.43 across centers, which is the highest effect size conferred by the known risk variants for PD. There is preliminary evidence that, overall, mutation carriers have an earlier age at onset (AAO), more atypical clinical manifestations, more cognitive changes and more likely to have affected relatives. ${ }^{[22,88]}$

\section{GENETIC VARIANTS IN INCONCLUSIVE OR NEGATIVE ASSOCIATION WITH PARKINSON'S DISEASE}

\section{Parkin}

The most frequent mutations in early-onset PD (EOPD) (AAO $\leq 50$ years) patients are those identified in the parkin gene, which account for up to $50 \%$ of autosomal recessive juvenile parkinsonism (AR-JP) and $15-20 \%$ of sporadic EOPD. ${ }^{[89-91]}$ Over 100 types of mutations including sequence substitutions, insertions and exonic deletions/duplications (or dosage mutations) in the parkin gene have been described in diverse ethnic groups. ${ }^{[92]}$ While homozygous or compound heterozygous mutations are causative, heterozygous mutations have been suggested to increase the risk for PD. ${ }^{[93,94]}$ The predisposing effects of heterozygote were, however, soon questioned by other studies in which they were reported as common in control subjects as in PD patients. ${ }^{[95,96]}$ These conflicting observations, as suggested by some studies, may come from the heterogeneous effects of different types of mutations, which may have different origins and pathogenic effects. For example, a haplotype analysis for a European EOPD family series demonstrated that exonic rearrangements occurred independently whereas point mutations may have been transmitted by a common founder. ${ }^{[97]}$ In addition, some studies suggested that dosage mutations are more pathogenic than sequence mutations in the development of familial PD. ${ }^{[98,99]}$ However, these results remain to be confirmed by large-scale studies, and it is unclear whether the dosage mutations are associated with typical sporadic PD.

\section{PINK1}

Mutations in the PTEN-induced putative kinase 1 (PINK-1) gene are the second common cause of autosomal recessive EOPD after parkin. The gene resides on chromosome 1p35-36 (PARK6) and encodes a protein locating on mitochondria. ${ }^{[100-102]}$ Evidences are gathering that PINK-1 is crucial for the normal functions of mitochondria and might participate in the detoxification of proteins. ${ }^{[103]}$ Different PINK-1 mutations including missense, nonsense, splice site mutations and entire PINK-1 gene deletion have been identified in both familial ${ }^{[104]}$ and sporadic EOPD cases, ${ }^{[105,106]}$ with a frequency ranging from $1 \%$ to $8 \%$. However, single heterozygous PINK-1 mutations have also been reported in healthy controls and large-scale case-control studies confirming the association between PINK-1 mutations, and sporadic PD are not available.

\section{DJ-1}

The DJ-1 gene (PARK7) encodes a protein belonging to the DJ-1/Thi/PfpI protein super family. It was initially described in association with oncogenesis and male rat infertility, ${ }^{[107,108]}$ and later found to be associated with autosomal recessive EOPD. ${ }^{[109,110]} \mathrm{DJ}-1$ is proposed to play a role in protecting neurons from oxidative stress and protecting against mitochondrial damage. ${ }^{[11]}$ A few PD-causing mutations have been identified, including exon deletions, truncations, homozygous and heterozygous point mutations, which predominantly result in loss of function. ${ }^{[109,112]}$ However, there is currently a lack of information about the frequency of 
mutations, including single heterozygous mutation, for DJ-1 in both familial and sporadic parkinsonism, especially in large population samples. Moreover, in a recent complete mutational analysis of DJ-1 coding sequence in a large cohort of familial and sporadic PD cases from 12 countries, none had causative mutation in DJ-1, suggesting its mutations are very rare in either familial or in sporadic parkinsonism. ${ }^{[13]]}$

\section{$\mathrm{UCH}-\mathrm{L} 1$}

The UCH-L1 gene (PARK5) encodes the ubiquitin carboxy-terminal hydrolase L1, which is a component of LB and possesses both a hydrolase activity to generate the ubiquitin monomer and a ligase activity to link ubiquitin molecules to tag proteins for disposal. ${ }^{[114]}$ The detection of an Ile93Met mutation in the UCH-L1 gene in a German family with autosomal dominant $\mathrm{PD}^{[115]}$ suggested a role for an impaired ubiquitin-proteasomal activity in PD pathogenesis. In contrast, a Ser18Tyr polymorphism affecting mainly the ligase activity has been suggested to have a protective effect in PD in some association studies. ${ }^{[116]}$ However, a subsequent large case-control study involving 3,044 PD cases and 3,252 controls, failed to replicate the association. ${ }^{[117]}$

\section{Omi/HtrA2}

The gene Omi/HtrA2 (PARK13) encodes a serine-protease with pro-apoptotic activity containing a mitochondrial targeting sequence at its $\mathrm{N}$-terminal region. ${ }^{[118]}$ Several lines of evidence in the literature support a role for Omi/HtrA2 in neurodegeneration. ${ }^{[119,120]}$ The first pathogenic mutation (G399S) a risk variant (A141S) for PD were identified in a German cohort. ${ }^{[121]}$ However, a later case-control study screening the whole coding region of Omi/HtrA2 revealed that neither of the two variants was overrepresented in the patients. ${ }^{[122]}$ Although another mutation, R404W, was found in Belgian PD patients, ${ }^{[123]}$ it is not clear whether it is associated with PD patients in other populations. Further, the most recent large-scale analysis of the five most informative SNPs spanning the Omi/HtrA2 gene in a cohort of 6,378 cases and 8,880 controls from 20 sites worldwide again confirmed the lacking of association of Omi/HtrA2 variants with PD. ${ }^{[124]}$ Therefore, the genetic basis for the involvement of $\mathrm{Omi} / \mathrm{HtrA} 2$ is still not conclusive at this point.

\section{GIGYF2}

Recently, it has been proposed that the GIGYF2 gene corresponds to the PARK11 locus causes a form of autosomal-recessive familial PD. ${ }^{[125,126]}$ In two independent French and Italian familial PD populations, 10 changes in 16 unrelated PD patients were found in the shortest form of GIGYF2, yielding a mutation frequency of $6.4 \% \cdot{ }^{[127]}$ However, no disease-causing mutations were found in other European populations ${ }^{[128]}$ and in recent months, over 10 replication studies have provided conflicting data, casting considerable doubt on the causal role of GIGYF2. ${ }^{[129]}$ In addition, a pooled analysis of over 4,500 PD and 5,500 controls revealed that the estimated frequency of GIGYF2 mutations in the entire replication cohort was only about $0.001 \%{ }^{[127]}$ Furthermore, the presence of mutations in healthy population controls or within asymptomatic family members of PD patients argues against causality even if longitudinal data are not available. Thus, unless new information emerges to suggest otherwise, it is reasonable to conclude that GIGYF2 does not play a major role in PD.

\section{VPS35}

The most recently described cause of monogenic PD is the mutations of a gene encoding vacuolar protein sorting-associated protein 35 (VPS35), which were identified by the next-generation of sequencing technique. ${ }^{[130,131]}$ Vilariño-Güell et al. ${ }^{[130]}$ described the identification of the p.D620N mutation in VPS35 within affected members of a Swiss kindred and three other families with late-onset, autosomal dominant PD, and in one sporadic PD case. At the same time, Zimprich et al. ${ }^{[131]}$ published the identification of the p.D620N mutation in a large multigenerational Austrian family with PD and in two additional families screened for VPS35 mutations. Both groups also identified additional mutations in VPS35; however, the pathogenicity of these additional variants remains unknown. Moreover, VPS35 mutations have been detected only in whites with PD. Studies in both Chinese and Japanese have excluded an association between VPS35 mutations and sporadic PD. ${ }^{[132-134]}$

\section{PLA2G6}

Mutations in phospholipase A2, group VI (PLA2G6) ${ }^{[135]}$ usually cause an early-onset recessive degenerative disorder with spasticity, ataxia and dystonia; however, later adult onset forms of the disease can present with a dystonia predominant parkinsonism. ${ }^{[136]}$ The patients with PLA2G6 homozygous mutations presented in their 20s with slowly progressive gait problems, clumsiness, imbalance, hand tremor, cognitive decline and dysarthria. Most patients with Parkinsonism are Levodopa-responsive at first, but this usually lasts only 1-2 years. PLA2G6 mutations have been screened for both early- and late-onset PD. Although SNPs have been identified in PD patients, none of these has been convincingly associated with the risk for PD. ${ }^{[137,138]}$

\section{EIF4G1}

Most recently, translation initiator mutations in EIF4G1 were genetically linked to autosomal dominant late-onset PD with brainstem Lewy body pathology. ${ }^{[139]}$ EIF4G1 is a central component of the EIF4F complex 
that regulates translation of mRNAs with highly structured 5'-sequences. The most popular mutations, p.Ala502Val and p.Arg1205His mutation were found to be with PD in some population. However, later replication studies in multiple ethnicities failed to confirm EIF4G1 mutations as a cause or a susceptible factor for familial or sporadic PD. ${ }^{[133,140,141]}$

\section{BST1}

Recently, GWAS in PD have provided association evidence at 16 loci, including a region encompassing a gene encoding bone marrow stromal cell antigen 1 (BST1) on 4p15. ${ }^{[142]}$ Interestingly, all PD-associated single-nucleotide polymorphisms (SNPs) on the BST1 locus lie within linkage disequilibrium blocks containing only the BST1 gene. ${ }^{[142]}$ However, by direct sequencing of the entire coding region of BST1, we did not reveal a variant associated with PD. ${ }^{[143]}$

\section{CONCERNS ON THE TRANSLATION OF GENETIC INFORMATION INTO CLINICAL APPLICATIONS}

Molecular diagnosis of Parkinson's disease: possibilities and concerns

As mutations in several genes are able to cause monogenic forms of PD, molecular diagnosis using these mutations for familial PD is possible. However, cautions must take before extensive applications of these mutations to genetic counseling, because most of our knowledge about the genetic basis of PD remains preliminary. According to the latest European Federation of Neurological Societies guidelines on the molecular diagnosis of $\mathrm{PD},{ }^{[144]}$ for mutations that are detected in rare familial forms of $\mathrm{PD}$, such as point mutation or multiplication of SNCA in familial PD, molecular diagnosis should be considered only for clearly familial cases. Even for the LRRK2 genes in which mutations are much more prevalent in Europeans, molecular testing is only recommended for cases with dominant inheritance of parkinsonian syndromes, and testing for the G2019S mutation is only recommended for familial and sporadic patients in the Ashkenazi Jews or North African Arabs. Similarly, testing for mutations in recessive PD-genes (parkin, PINK-1, DJ-1) is only recommended for families suggestive of recessive inheritance (affected sib pairs) or sporadic patients with very early onset ( $<35$ years). For most of the other mutations, using of them for genetic testing should wait until their causative role in the disease is convincingly established.

Use of genetic variation as predictive biomarkers for Parkinson's disease: is it possible now?

A biomarker is a substance used as an indicator of normal biologic and pathogenic processes, or responses to a therapeutic intervention. Biomarkers for PD may be directed at disease risk, disease progression, or both. A mutation or genetic variant can be considered a risk biomarker for PD if it is associated with the disease. The discovery of mutations that cause monogenetic forms of PD has allowed clinical investigators to determine the cause of the disease and to predict the risk for developing the disease. However, at least two factors have to be simultaneously considered before defining such mutations as biomarkers: the penetrance of the mutations and the variability of AAO of PD caused by the mutations. Mutations that confer high risk of developing a disease usually display a high penetrance ( $>80 \%$ ), and the variability of AAOs of patients carrying such mutations is usually low. In autosomal dominant form of PD, the most affirmatively causative mutations are those within the SNCA and LRRK2 genes. Point mutations, duplications, and triplications of SNCA cause PD with high penetrance. However, the AAO of each mutation type in this gene is associated with a fairly high variability among cases (ranging from mid- 30s to late 80s), making it difficult to use these mutations to predict the onset and course. On the other hand, although the causative role of the LRRK2 G2019S mutation is not in question, and the AAO is less variable (usually at 60s), it is clear that the penetrance of this gene is only $30-40 \%$. Therefore, carrying this mutation does not unequivocally predict development of PD during a lifetime. ${ }^{[145]}$ The situation for the risk variants associated with the onset and progression of sporadic PD are even more complicated and puzzling as it may involve multiple independent and interactive factors. Thus, the value of a genetic biomarker in predicting an individual's risk of developing the disease is questionable at the current stage.

Can genetic variations help in molecular classification of Parkinsonian disorders?

Parkinsonian disorders are a group of clinically and pathogenically diverse disorders. For diagnostic and therapeutic purposes, it has long been expected to classify this clinical complex further. Currently, the classification of these disorders is mainly based on pathological findings. According to autopsy findings, the histological characteristics in the patients' brain have been classified as $\alpha$-synucleinopathies and non- $\alpha$-synucleinopathies, the latter including tauopathies, TDP-43 proteinopathies and nonspecific degeneration in the pars compacta of the substantia nigra (SNPc). ${ }^{[146]}$ However, this classification is made postpartum and, therefore, less useful for preclinical and clinical diagnosis. Interestingly, studies have demonstrated that similar pathologies might result from the influence of mutations in genes that are part of the same pathways. ${ }^{[11,147]}$ For example, PD cases with mutations in SNCA, LRRK2 and GBA genes usually display a common $\alpha$-synuclein pathology, 
while those with mutations in the MAPT gene tend to possess both $\alpha$-synuclein and tau pathologies. In contrast, except for nonspecific neuronal loss and gliosis, no histopathological hallmark was revealed in most of the AR-JP patients caused by mutations in the parkin gene. ${ }^{[146]}$ Moreover, many variations in these genes are not only associated with increased risk for PD, but strongly correlate with certain profiles of the disease. Hence, it is reasonable to assume that genetically determined loci, especially when combined with pathological and clinical information, can help in establishing a classification for PD. In a recent study, we have investigated clinical profiles of $\mathrm{PD}$ related to LRRK2 (LRRK2-PD), GBA (GBA-PD) variant, or none of the variants (idiopathic PD, IPD). ${ }^{[148]}$ As a result, LRRK2-PD is largely similar to IPD, while GBA-PD patients had an earlier onset and more frequent and severe nonmotor symptoms. These results favor the feasibility of genetic classification of PD. However, since much of our knowledge about the genetic-pathologic-clinical axis of parkinsonism is quite limited so far, there is still a long way ahead before a rational nosology for parkinsonian disorders linked to their genetic underpinnings is made and before the classification becomes a practice guideline.

\section{CONCLUDING REMARKS AND FUTURE RESEARCH CONCERNS}

The past decade has been an exciting time for investigators involved in genetic research in PD. The rapidly emerging evidences of the genetic contribution to PD have changed the way we think about the disease. However, we are still not able to see a complete genetic picture of the disease. Many concerns remain to be addressed. First, the highly genetic heterogeneity among populations reminds us that the genetic information of a gene or locus provided by current studies for certain populations is limiting and segmentary. For example, although the link of the LRKK2 G2019S mutation to PD in multiple populations has been well-established, it provides little information for Eastern Asians. The emerging evidences for the contribution of another variant, G2385R, residing in a different domain of the protein may suggest a yet-unknown, but sharply different story of LRRK2 from that of the G2019S mutation. Thus, before characterizing the roles played by G2385R or other potential significant variants, a complete genetic behavior of LRRK2 should not be described merely by the G2019S information, nor should it be applied extensively to clinical practice. Similarly, it is not reasonable to overestimate the genetic contribution of the $\mathrm{H} 1$ haplotype of MAPT gene because the homozygous $\mathrm{H} 1$ allele is dominant while the $\mathrm{H} 2$ haplotype lacks in Asians. These problems necessitate clinical and genetic studies surrounding the population-specific variants. Second, most of the current genetic studies are focused on sequence variations (i.e. point mutations or SNPs) and much less have been directed to copy-number variations (CNVs), whose pathogenic or predisposing effects sometimes are even more evident and important. Dosage mutations of the parkin gene, for instance, have been suggested to be more pathogenic than the sequence mutations for familial PD among Europeans. Therefore, large-scale and multi-central analysis of CNVs are urgently needed to improve the image of risk genetic variants for PD. Third, the work on genetic mechanisms underlying PD is far away from just identifying mutations or risk variants. We have to figure out how these variants act on the disease, e.g. how they interact with other genes and/or environmental factors, and how they are linked to pathophysiological pathways involved in PD. In addition, prospective studies of presymptomatic carriers of mutations or risk genetic variants of PD genes are necessary to confirm their genetic roles in the disease development and progression.

\section{ACKNOWLEDGMENTS}

This study was supported by grants from National Natural Science Foundation of China (No. 81371320), the Project for Young and Middle-Aged Talents of Fujian Health Care System, No. 2013-ZQN-JC-29 to Dr. Chao-Dong Wang, and the Ministry of Science and Technology of China (2012AA02A514), the National Basic Research Development Program of China (2011CB504101) to Dr. Piu Chan.

\section{REFERENCES}

1. Farrer MJ. Genetics of Parkinson disease: paradigm shifts and future prospects. Nat Rev Genet 2006; 7:306-18.

2. Braak H, Rüb U, Gai WP, Del Tredici K. Idiopathic Parkinson's disease: possible routes by which vulnerable neuronal types may be subject to neuroinvasion by an unknown pathogen. $J$ Neural Transm 2003;110:517-36.

3. Forno LS. Neuropathology of Parkinson's disease. J Neuropathol Exp Neurol 1996;55:259-72.

4. Rosner S, Giladi N, Orr-Urtreger A. Advances in the genetics of Parkinson's disease. Acta Pharmacol Sin 2008;29:21-34.

5. Sulzer D. Multiple hit hypotheses for dopamine neuron loss in Parkinson's disease. Trends Neurosci 2007;30:244-50.

6. Dawson TM, Dawson VL. Molecular pathways of neurodegeneration in Parkinson's disease. Science 2003;302:819-22.

7. Klein C, Schlossmacher MG. Parkinson disease, 10 years after its genetic revolution: multiple clues to a complex disorder. Neurology 2007;69:2093-104.

8. Thomas B, Beal MF. Parkinson's disease. Hum Mol Genet 2007;16 Spec No 2:R183-94.

9. Hardy J, Cai H, Cookson MR, Gwinn-Hardy K, Singleton A. Genetics of Parkinson's disease and parkinsonism. Ann Neurol 2006;60:389-98.

10. Tan EK, Skipper LM. Pathogenic mutations in Parkinson disease. Hum Mutat 2007;28:641-53.

11. Gasser T. Update on the genetics of Parkinson's disease. Mov Disord 2007;22 Suppl 17:S343-50.

12. Satake W, Nakabayashi Y, Mizuta I, Hirota Y, Ito C, Kubo M, Kawaguchi T, Tsunoda T, Watanabe M, Takeda A, Tomiyama H, 
Nakashima K, Hasegawa K, Obata F, Yoshikawa T, Kawakami H, Sakoda S, Yamamoto M, Hattori N, Murata M, Nakamura Y, Toda T. Genome-wide association study identifies common variants at four loci as genetic risk factors for Parkinson's disease. Nat Genet 2009;41:1303-7.

13. Simón-Sánchez J, Schulte C, Bras JM, Sharma M, Gibbs JR, Berg D, Paisan-Ruiz C, Lichtner P, Scholz SW, Hernandez DG, Krüger R, Federoff M, Klein C, Goate A, Perlmutter J, Bonin M, Nalls MA, Illig T, Gieger C, Houlden H, Steffens M, Okun MS, Racette BA, Cookson MR, Foote KD, Fernandez HH, Traynor BJ, Schreiber S, Arepalli S, Zonozi R, Gwinn K, van der Brug M, Lopez G, Chanock SJ, Schatzkin A, Park Y, Hollenbeck A, Gao J, Huang X, Wood NW, Lorenz D, Deuschl G, Chen H, Riess O, Hardy JA, Singleton AB, Gasser T. Genome-wide association study reveals genetic risk underlying Parkinson's disease. Nat Genet 2009;41:1308-12.

14. Edwards TL, Scott WK, Almonte C, Burt A, Powell EH, Beecham GW, Wang L, Züchner S, Konidari I, Wang G, Singer C, Nahab F, Scott B, Stajich JM, Pericak-Vance M, Haines J, Vance JM, Martin ER. Genome-wide association study confirms SNPs in SNCA and the MAPT region as common risk factors for Parkinson disease. Ann Hum Genet 2010;74:97-109.

15. Fung HC, Scholz S, Matarin M, Simón-Sánchez J, Hernandez D, Britton A, Gibbs JR, Langefeld C, Stiegert ML, Schymick J, Okun MS, Mandel RJ, Fernandez HH, Foote KD, Rodríguez RL, Peckham E, De Vrieze FW, Gwinn-Hardy K, Hardy JA, Singleton A. Genome-wide genotyping in Parkinson's disease and neurologically normal controls: first stage analysis and public release of data. Lancet Neurol 2006;5:911-6.

16. Kumar KR, Lohmann K, Klein C. Genetics of Parkinson disease and other movement disorders. Curr Opin Neurol 2012;25:466-74.

17. Bras JM, Singleton AB. Exome sequencing in Parkinson's disease. Clin Genet 2011;80:104-9.

18. Spillantini MG, Schmidt ML, Lee VM, Trojanowski JQ, Jakes R, Goedert M. Alpha-synuclein in Lewy bodies. Nature 1997;388:839-40

19. Polymeropoulos MH, Lavedan C, Leroy E, Ide SE, Dehejia A, Dutra A, Pike B, Root H, Rubenstein J, Boyer R, Stenroos ES, Chandrasekharappa S, Athanassiadou A, Papapetropoulos T, Johnson WG, Lazzarini AM, Duvoisin RC, Di Iorio G, Golbe LI, Nussbaum RL. Mutation in the alpha-synuclein gene identified in families with Parkinson's disease. Science 1997;276:2045-7.

20. Krüger R, Kuhn W, Müller T, Woitalla D, Graeber M, Kösel S, Przuntek H, Epplen JT, Schöls L, Riess O. Ala30Pro mutation in the gene encoding alpha-synuclein in Parkinson's disease. Nat Genet 1998;18:106-8.

21. Zarranz JJ, Alegre J, Gómez-Esteban JC, Lezcano E, Ros R, Ampuero I, Vidal L, Hoenicka J, Rodriguez O, Atarés B, Llorens V, Gomez Tortosa E, del Ser T, Muñoz DG, de Yebenes JG. The new mutation, E46K, of alpha-synuclein causes Parkinson and Lewy body dementia. Ann Neurol 2004;55:164-73.

22. Nagar S, Juyal RC, Chaudhary S, Behari M, Gupta M, Rao SN, Thelma BK. Mutations in the alpha-synuclein gene in Parkinson's disease among Indians. Acta Neurol Scand 2001;103:120-2.

23. Mizuta I, Satake W, Nakabayashi Y, Ito C, Suzuki S, Momose Y, Nagai Y, Oka A, Inoko H, Fukae J, Saito Y, Sawabe M, Murayama S, Yamamoto M, Hattori N, Murata M, Toda T. Multiple candidate gene analysis identifies alpha-synuclein as a susceptibility gene for sporadic Parkinson's disease. Hum Mol Genet 2006;15:1151-8.

24. Chartier-Harlin MC, Kachergus J, Roumier C, Mouroux V, Douay X, Lincoln S, Levecque C, Larvor L, Andrieux J, Hulihan M, Waucquier N, Defebvre L, Amouyel P, Farrer M, Destée A. Alpha-synuclein locus duplication as a cause of familial Parkinson's disease. Lancet 2004;364:1167-9.

25. Fuchs J, Nilsson C, Kachergus J, Munz M, Larsson EM, Schüle B, Langston JW, Middleton FA, Ross OA, Hulihan M, Gasser T, Farrer MJ. Phenotypic variation in a large Swedish pedigree due to SNCA duplication and triplication. Neurology 2007;68:916-22.

26. Ibáñez P, Bonnet AM, Débarges B, Lohmann E, Tison F, Pollak P, Agid Y, Dürr A, Brice A. Causal relation between alpha-synuclein gene duplication and familial Parkinson's disease. Lancet 2004;364:1169-71

27. Ikeuchi T, Kakita A, Shiga A, Kasuga K, Kaneko H, Tan CF, Idezuka J, Wakabayashi K, Onodera O, Iwatsubo T, Nishizawa M, Takahashi H, Ishikawa A. Patients homozygous and heterozygous for SNCA duplication in a family with parkinsonism and dementia. Arch Neurol 2008;65:514-9.

28. Nishioka K, Hayashi S, Farrer MJ, Singleton AB, Yoshino H, Imai H, Kitami T, Sato K, Kuroda R, Tomiyama H, Mizoguchi K, Murata M, Toda T, Imoto I, Inazawa J, Mizuno Y, Hattori N. Clinical heterogeneity of alpha-synuclein gene duplication in Parkinson's disease. Ann Neurol 2006;59:298-309.

29. Singleton $A B$, Farrer MJ, Johnson J, Singleton A, Hague $S$, Kachergus J, Hulihan M, Peuralinna T, Dutra A, Nussbaum R, Lincoln S, Crawley A, Hanson M, Maraganore D, Adler C, Cookson MR, Muenter M, Baptista M, Miller D, Blancato J, Hardy J, Gwinn-Hardy K. Alpha-synuclein locus triplication causes Parkinson's disease. Science 2003;302:841.

30. Ahn TB, Kim SY, Kim JY, Park SS, Lee DS, Min HJ, Kim YK, Kim SE Kim JM, Kim HJ, Cho J, Jeon BS. Alpha-synuclein gene duplication is present in sporadic Parkinson disease. Neurology 2008;70:43-9.

31. Ross OA, Braithwaite AT, Skipper LM, Kachergus J, Hulihan MM, Middleton FA, Nishioka K, Fuchs J, Gasser T, Maraganore DM, Adler CH, Larvor L, Chartier-Harlin MC, Nilsson C, Langston JW, Gwinn K, Hattori N, Farrer MJ. Genomic investigation of alpha-synuclein multiplication and parkinsonism. Ann Neurol 2008;63:743-50.

32. Chiba-Falek O, Lopez GJ, Nussbaum RL. Levels of alpha-synuclein mRNA in sporadic Parkinson disease patients. Mov Disord 2006;21:1703-8.

33. Gründemann J, Schlaudraff F, Haeckel O, Liss B. Elevated alpha-synuclein mRNA levels in individual UV-laser-microdissected dopaminergic substantia nigra neurons in idiopathic Parkinson's disease. Nucleic Acids Res 2008;36:e38.

34. Rockenstein E, Hansen LA, Mallory M, Trojanowski JQ, Galasko D, Masliah E. Altered expression of the synuclein family mRNA in Lewy body and Alzheimer's disease. Brain Res 2001;914:48-56.

35. Tan EK, Chandran VR, Fook-Chong S, Shen H, Yew K, Teoh ML, Yuen Y, Zhao Y. Alpha-synuclein mRNA expression in sporadic Parkinson's disease. Mov Disord 2005;20:620-3.

36. Farrer M, Maraganore DM, Lockhart P, Singleton A, Lesnick TG, de Andrade M, West A, de Silva R, Hardy J, Hernandez D Alpha-synuclein gene haplotypes are associated with Parkinson's disease. Hum Mol Genet 2001;10:1847-51.

37. Tan EK, Tan C, Shen H, Chai A, Lum SY, Teoh ML, Yih Y, Wong MC, Zhao Y. Alpha synuclein promoter and risk of Parkinson's disease: microsatellite and allelic size variability. Neurosci Lett 2003;336:70-2.

38. Pals P, Lincoln S, Manning J, Heckman M, Skipper L, Hulihan M, Van den Broeck M, De Pooter T, Cras P, Crook J, Van Broeckhoven C, Farrer MJ. alpha-Synuclein promoter confers susceptibility to Parkinson's disease. Ann Neurol 2004;56:591-5.

39. Mellick GD, Maraganore DM, Silburn PA. Australian data and meta-analysis lend support for alpha-synuclein (NACP-Rep1) as a risk factor for Parkinson's disease. Neurosci Lett 2005;375:112-6.

40. Maraganore DM, de Andrade M, Elbaz A, Farrer MJ, Ioannidis JP, Krüger R, Rocca WA, Schneider NK, Lesnick TG, Lincoln SJ, Hulihan MM, Aasly JO, Ashizawa T, Chartier-Harlin MC, Checkoway H, Ferrarese C, Hadjigeorgiou G, Hattori N, Kawakami H, Lambert JC, Lynch T, Mellick GD, Papapetropoulos S, Parsian A, Quattrone A, Riess O, Tan EK, Van Broeckhoven C; Genetic Epidemiology of Parkinson's Disease (GEO-PD) Consortium. Collaborative analysis of alpha-synuclein gene promoter variability and Parkinson disease. JAMA 2006;296:661-70.

41. Winkler S, Hagenah J, Lincoln S, Heckman M, Haugarvoll K, Lohmann-Hedrich K, Kostic V, Farrer M, Klein C. Alpha-synuclein and Parkinson disease susceptibility. Neurology 2007;69:1745-50

42. An JJ, Gharami K, Liao GY, Woo NH, Lau AG, Vanevski F, Torre ER, Jones KR, Feng Y, Lu B, Xu B. Distinct role of long 3' UTR BDNF 
mRNA in spine morphology and synaptic plasticity in hippocampal neurons. Cell 2008;134:175-87.

43. Mikulits W, Schranzhofer M, Beug H, Müllner EW. Post-transcriptional control via iron-responsive elements: the impact of aberrations in hereditary disease. Mutat Res 1999;437:219-30.

44. Mizuta I, Satake W, Nakabayashi Y, Ito C, Suzuki S, Momose Y, Nagai Y, Oka A, Inoko H, Fukae J, Saito Y, Sawabe M, Murayama S, Yamamoto M, Hattori N, Murata M, Toda T. Multiple candidate gene analysis identifies alpha-synuclein as a susceptibility gene for sporadic Parkinson's disease. Hum Mol Genet 2006;15:1151-8.

45. Myhre R, Toft M, Kachergus J, Hulihan MM, Aasly JO, Klungland H, Farrer MJ. Multiple alpha-synuclein gene polymorphisms are associated with Parkinson's disease in a Norwegian population. Acta Neurol Scand 2008;118:320-7.

46. Ross OA, Gosal D, Stone JT, Lincoln SJ, Heckman MG, Irvine GB, Johnston JA, Gibson JM, Farrer MJ, Lynch T. Familial genes in sporadic disease: common variants of alpha-synuclein gene associate with Parkinson's disease. Mech Ageing Dev 2007;128:378-82.

47. Rajput A, Vilariño-Güell C, Rajput ML, Ross OA, Soto-Ortolaza AI, Lincoln SJ, Cobb SA, Heckman MG, Farrer MJ, Rajput A. Alpha-synuclein polymorphisms are associated with Parkinson's disease in a Saskatchewan population. Mov Disord 2009;24:2411-4.

48. Fuchs J, Tichopad A, Golub Y, Munz M, Schweitzer KJ, Wolf B, Berg D, Mueller JC, Gasser T. Genetic variability in the SNCA gene influences alpha-synuclein levels in the blood and brain. FASEB $J$ 2008;22:1327-34

49. Paisán-Ruíz C, Jain S, Evans EW, Gilks WP, Simón J, van der Brug M, López de Munain A, Aparicio S, Gil AM, Khan N, Johnson J, Martinez JR, Nicholl D, Carrera IM, Pena AS, de Silva R, Lees A, Martí-Massó JF, Pérez-Tur J, Wood NW, Singleton AB. Cloning of the gene containing mutations that cause PARK8-linked Parkinson's disease. Neuron 2004;44:595-600.

50. Zimprich A, Biskup S, Leitner P, Lichtner P, Farrer M, Lincoln S, Kachergus J, Hulihan M, Uitti RJ, Calne DB, Stoessl AJ, Pfeiffer RF, Patenge N, Carbajal IC, Vieregge P, Asmus F, Müller-Myhsok B, Dickson DW, Meitinger T, Strom TM, Wszolek ZK, Gasser T. Mutations in LRRK2 cause autosomal-dominant parkinsonism with pleomorphic pathology. Neuron 2004;44:601-7.

51. Di Fonzo A, Rohé CF, Ferreira J, Chien HF, Vacca L, Stocchi F, Guedes L, Fabrizio E, Manfredi M, Vanacore N, Goldwurm S, Breedveld G, Sampaio C, Meco G, Barbosa E, Oostra BA, Bonifati V; Italian Parkinson Genetics Network. A frequent LRRK2 gene mutation associated with autosomal dominant Parkinson's disease. Lancet 2005;365:412-5.

52. Gilks WP, Abou-Sleiman PM, Gandhi S, Jain S, Singleton A, Lees AJ, Shaw K, Bhatia KP, Bonifati V, Quinn NP, Lynch J, Healy DG, Holton JL, Revesz T, Wood NW. A common LRRK2 mutation in idiopathic Parkinson's disease. Lancet 2005;365:415-6.

53. Ozelius LJ, Senthil G, Saunders-Pullman R, Ohmann E, Deligtisch A, Tagliati M, Hunt AL, Klein C, Henick B, Hailpern SM, Lipton RB, Soto-Valencia J, Risch N, Bressman SB. LRRK2 G2019S as a cause of Parkinson's disease in Ashkenazi Jews. N Engl J Med 2006;354:424-5.

54. Lesage S, Dürr A, Tazir M, Lohmann E, Leutenegger AL, Janin S, Pollak P, Brice A; French Parkinson's Disease Genetics Study Group. LRRK2 G2019S as a cause of Parkinson's disease in North African Arabs. N Engl J Med 2006;354:422-3.

55. Ishihara L, Gibson RA, Warren L, Amouri R, Lyons K, Wielinski C, Hunter C, Swartz JE, Elango R, Akkari PA, Leppert D, Surh L, Reeves KH, Thomas S, Ragone L, Hattori N, Pahwa R, Jankovic J, Nance M, Freeman A, Gouider-Khouja N, Kefi M, Zouari M, Ben Sassi S, Ben Yahmed S, El Euch-Fayeche G, Middleton L, Burn DJ, Watts RL, Hentati F. Screening for Lrrk2 G2019S and clinical comparison of Tunisian and North American Caucasian Parkinson's disease families. Mov Disord 2007;22:55-61.

56. Hulihan MM, Ishihara-Paul L, Kachergus J, Warren L, Amouri R, Elango R, Prinjha RK, Upmanyu R, Kefi M, Zouari M, Sassi SB, Yahmed SB, El Euch-Fayeche G, Matthews PM, Middleton LT, Gibson RA, Hentati F, Farrer MJ. LRRK2 Gly2019Ser penetrance in Arab-Berber patients from Tunisia: a case-control genetic study Lancet Neurol 2008;7:591-4.

57. Healy DG, Falchi M, O'Sullivan SS, Bonifati V, Durr A, Bressman S, Brice A, Aasly J, Zabetian CP, Goldwurm S, Ferreira JJ, Tolosa E, Kay DM, Klein C, Williams DR, Marras C, Lang AE, Wszolek ZK, Berciano J, Schapira AH, Lynch T, Bhatia KP, Gasser T, Lees AJ, Wood NW; International LRRK2 Consortium. Phenotype, genotype, and worldwide genetic penetrance of LRRK2-associated Parkinson's disease: a case-control study. Lancet Neurol 2008;7:583-90.

58. Tan EK, Shen H, Tan LC, Farrer M, Yew K, Chua E, Jamora RD, Puvan K, Puong KY, Zhao Y, Pavanni R, Wong MC, Yih Y, Skipper L, Liu JJ. The G2019S LRRK2 mutation is uncommon in an Asian cohort of Parkinson's disease patients. Neurosci Lett 2005;384:327-9.

59. Lu CS, Simons EJ, Wu-Chou YH, Fonzo AD, Chang HC, Chen RS Weng YH, Rohé CF, Breedveld GJ, Hattori N, Gasser T, Oostra BA, Bonifati V. The LRRK2 I2012T, G2019S, and I2020T mutations are rare in Taiwanese patients with sporadic Parkinson's disease. Parkinsonism Relat Disord 2005;11:521-2.

60. Okubadejo N, Britton A, Crews C, Akinyemi R, Hardy J, Singleton A, Bras J. Analysis of Nigerians with apparently sporadic Parkinson disease for mutations in LRRK2, PRKN and ATXN3. PLoS One 2008;3:e3421.

61. Di Fonzo A, Wu-Chou YH, Lu CS, van Doeselaar M, Simons EJ, Rohé CF, Chang HC, Chen RS, Weng YH, Vanacore N, Breedveld GJ, Oostra BA, Bonifati V. A common missense variant in the LRRK2 gene, Gly2385Arg, associated with Parkinson's disease risk in Taiwan. Neurogenetics 2006;7:133-8.

62. Farrer MJ, Stone JT, Lin CH, Dächsel JC, Hulihan MM Haugarvoll K, Ross OA, Wu RM. Lrrk2 G2385R is an ancestral risk factor for Parkinson's disease in Asia. Parkinsonism Relat Disord 2007;13:89-92.

63. An XK, Peng R, Li T, Burgunder JM, Wu Y, Chen WJ, Zhang JH, Wang YC, Xu YM, Gou YR, Yuan GG, Zhang ZJ. LRRK2 Gly2385Arg variant is a risk factor of Parkinson's disease among Han-Chinese from mainland China. Eur J Neurol 2008;15:301-5.

64. Lu CS, Wu-Chou YH, van Doeselaar M, Simons EJ, Chang HC, Breedveld GJ, Di Fonzo A, Chen RS, Weng YH, Lai SC, Oostra BA, Bonifati V. The LRRK2 Arg1628Pro variant is a risk factor for Parkinson's disease in the Chinese population. Neurogenetics 2008;9:271-6.

65. Zhang Z, Burgunder JM, An X, Wu Y, Chen W, Zhang J, Wang Y, Xu Y, Gou Y, Yuan G, Mao X, Peng R. LRRK2 R1628P variant is a risk factor of Parkinson's disease among Han-Chinese from mainland China. Mov Disord 2009;24:1902-5.

66. Hutton M, Lendon CL, Rizzu P, Baker M, Froelich S, Houlden H, Pickering-Brown S, Chakraverty S, Isaacs A, Grover A, Hackett J, Adamson J, Lincoln S, Dickson D, Davies P, Petersen RC, Stevens M, de Graaff E, Wauters E, van Baren J, Hillebrand M, Joosse M, Kwon JM, Nowotny P, Che LK, Norton J, Morris JC, Reed LA, Trojanowski J, Basun H, Lannfelt L, Neystat M, Fahn S, Dark F, Tannenberg T, Dodd PR, Hayward N, Kwok JB, Schofield PR, Andreadis A, Snowden J, Craufurd D, Neary D, Owen F, Oostra BA, Hardy J, Goate A, van Swieten J, Mann D, Lynch T, Heutink P. Association of missense and 5'-splice-site mutations in tau with the inherited dementia FTDP-17. Nature 1998;393:702-5.

67. Kwok JB, Teber ET, Loy C, Hallupp M, Nicholson G, Mellick GD, Buchanan DD, Silburn PA, Schofield PR. Tau haplotypes regulate transcription and are associated with Parkinson's disease. Ann Neurol 2004;55:329-34.

68. Zabetian CP, Hutter CM, Factor SA, Nutt JG, Higgins DS, Griffith A, Roberts JW, Leis BC, Kay DM, Yearout D, Montimurro JS, Edwards KL, Samii A, Payami H. Association analysis of MAPT H1 haplotype and subhaplotypes in Parkinson's disease. Ann Neurol 2007;62:137-44

69. Williams-Gray CH, Evans JR, Goris A, Foltynie T, Ban M, Robbins TW, Brayne C, Kolachana BS, Weinberger DR, Sawcer SJ, Barker RA. The distinct cognitive syndromes of Parkinson's disease: 5 year follow-up of the CamPaIGN cohort. Brain 2009;132:2958-69.

70. Evans W, Fung HC, Steele J, Eerola J, Tienari P, Pittman A, 
Silva Rd, Myers A, Vrieze FW, Singleton A, Hardy J. The tau H2 haplotype is almost exclusively Caucasian in origin. Neurosci Lett 2004;369:183-5.

71. Skipper L, Wilkes K, Toft M, Baker M, Lincoln S, Hulihan M, Ross OA, Hutton M, Aasly J, Farrer M. Linkage disequilibrium and association of MAPT H1 in Parkinson disease. Am J Hum Genet 2004; 75:669-77.

72. Fidani L, Kalinderi K, Bostantjopoulou S, Clarimon J, Goulas A, Katsarou Z, Hardy J, Kotsis A. Association of the Tau haplotype with Parkinson's disease in the Greek population. Mov Disord 2006;21:1036-9.

73. Refenes N, Bolbrinker J, Tagaris G, Orlacchio A, Drakoulis N, Kreutz R. Role of the $\mathrm{H} 1$ haplotype of microtubule-associated protein tau (MAPT) gene in Greek patients with Parkinson's disease. BMC Neurol 2009;9:26.

74. Fung HC, Xiromerisiou G, Gibbs JR, Wu YR, Eerola J, Gourbali V, Hellström O, Chen CM, Duckworth J, Papadimitriou A, Tienari PJ, Hadjigeorgiou GM, Hardy J, Singleton AB. Association of tau haplotype-tagging polymorphisms with Parkinson's disease in diverse ethnic Parkinson's disease cohorts. Neurodegener Dis 2006;3:327-33.

75. Beutler E. Gaucher disease: new molecular approaches to diagnosis and treatment. Science 1992;256:794-9.

76. Hruska KS, LaMarca ME, Scott CR, Sidransky E. Gaucher disease: mutation and polymorphism spectrum in the glucocerebrosidase gene (GBA). Hum Mutat 2008;29:567-83.

77. Tayebi N, Walker J, Stubblefield B, Orvisky E, LaMarca ME, Wong K, Rosenbaum H, Schiffmann R, Bembi B, Sidransky E. Gaucher disease with parkinsonian manifestations: does glucocerebrosidase deficiency contribute to a vulnerability to parkinsonism? Mol Genet Metab 2003;79:104-9.

78. Lwin A, Orvisky E, Goker-Alpan O, LaMarca ME, Sidransky E. Glucocerebrosidase mutations in subjects with parkinsonism. Mol Genet Metab 2004;81:70-3.

79. Aharon-Peretz J, Badarny S, Rosenbaum H, Gershoni-Baruch R. Mutations in the glucocerebrosidase gene and Parkinson disease: phenotype-genotype correlation. Neurology 2005;65:1460-1.

80. Gan-Or Z, Giladi N, Rozovski U, Shifrin C, Rosner S, Gurevich T, Bar-Shira A, Orr-Urtreger A. Genotype-phenotype correlations between GBA mutations and Parkinson disease risk and onset. Neurology 2008;70:2277-83.

81. Kalinderi K, Bostantjopoulou S, Paisan-Ruiz C, Katsarou Z, Hardy J, Fidani L. Complete screening for glucocerebrosidase mutations in Parkinson disease patients from Greece. Neurosci Lett 2009;452:87-9.

82. Neumann J, Bras J, Deas E, O'Sullivan SS, Parkkinen L, Lachmann RH, Li A, Holton J, Guerreiro R, Paudel R, Segarane B, Singleton A, Lees A, Hardy J, Houlden H, Revesz T, Wood NW. Glucocerebrosidase mutations in clinical and pathologically proven Parkinson's disease. Brain 2009;132:1783-94.

83. Spitz M, Rozenberg R, Pereira Lda V, Reis Barbosa E. Association between Parkinson's disease and glucocerebrosidase mutations in Brazil. Parkinsonism Relat Disord 2008;14:58-62.

84. Wan L, Hsu CM, Tsai CH, Lee CC, Hwu WL, Tsai FJ. Mutation analysis of Gaucher disease patients in Taiwan: high prevalence of the RecNcil and L444P mutations. Blood Cells Mol Dis 2006;36:422-5

85. Tayebi N, Stubblefield BK, Park JK, Orvisky E, Walker JM, LaMarca ME, Sidransky E. Reciprocal and nonreciprocal recombination at the glucocerebrosidase gene region: implications for complexity in Gaucher disease. Am J Hum Genet 2003;72:519-34.

86. Sidransky E, Nalls MA, Aasly JO, Aharon-Peretz J, Annesi G, Barbosa ER, Bar-Shira A, Berg D, Bras J, Brice A, Chen CM, Clark LN, Condroyer C, De Marco EV, Dürr A, Eblan MJ, Fahn S, Farrer MJ, Fung HC, Gan-Or Z, Gasser T, Gershoni-Baruch R, Giladi N, Griffith A, Gurevich T, Januario C, Kropp P, Lang AE, Lee-Chen GJ, Lesage S, Marder K, Mata IF, Mirelman A, Mitsui J, Mizuta I, Nicoletti G, Oliveira C, Ottman R, Orr-Urtreger A, Pereira LV, Quattrone A, Rogaeva E, Rolfs A, Rosenbaum H,
Rozenberg R, Samii A, Samaddar T, Schulte C, Sharma M, Singleton A, Spitz M, Tan EK, Tayebi N, Toda T, Troiano AR, Tsuji S, Wittstock M, Wolfsberg TG, Wu YR, Zabetian CP, Zhao Y, Ziegler SG. Multicenter analysis of glucocerebrosidase mutations in Parkinson's disease. N Engl J Med 2009;361:1651-61.

87. DePaolo J, Goker-Alpan O, Samaddar T, Lopez G, Sidransky E. The association between mutations in the lysosomal protein glucocerebrosidase and parkinsonism. Mov Disord 2009 15;24:1571-8.

88. Goker-Alpan O, Lopez G, Vithayathil J, Davis J, Hallett M Sidransky $E$. The spectrum of parkinsonian manifestations associated with glucocerebrosidase mutations. Arch Neurol 2008;65:1353-7.

89. Kitada T, Asakawa S, Hattori N, Matsumine H, Yamamura Y, Minoshima S, Yokochi M, Mizuno Y, Shimizu N. Mutations in the parkin gene cause autosomal recessive juvenile parkinsonism. Nature 1998;392:605-8.

90. Dekker MC, Bonifati V, van Duijn CM. Parkinson's disease: piecing together a genetic jigsaw. Brain 2003;126:1722-33.

91. Periquet M, Latouche M, Lohmann E, Rawal N, De Michele G Ricard S, Teive H, Fraix V, Vidailhet M, Nicholl D, Barone P, Wood NW, Raskin S, Deleuze JF, Agid Y, Dürr A, Brice A; French Parkinson's Disease Genetics Study Group; European Consortium on Genetic Susceptibility in Parkinson's Disease. Parkin mutations are frequent in patients with isolated early-onset parkinsonism. Brain 2003;126:1271-8.

92. Hedrich K, Eskelson C, Wilmot B, Marder K, Harris J, Garrels J Meija-Santana H, Vieregge P, Jacobs H, Bressman SB, Lang AE, Kann M, Abbruzzese G, Martinelli P, Schwinger E, Ozelius LJ, Pramstaller PP, Klein C, Kramer P. Distribution, type, and origin of Parkin mutations: review and case studies. Mov Disord 2004;19:1146-57.

93. Foroud T, Uniacke SK, Liu L, Pankratz N, Rudolph A, Halter C, Shults C, Marder K, Conneally PM, Nichols WC; Parkinson Study Group. Heterozygosity for a mutation in the parkin gene leads to later onset Parkinson disease. Neurology 2003;60:796-801.

94. Sun M, Latourelle JC, Wooten GF, Lew MF, Klein C, Shill HA, Golbe LI, Mark MH, Racette BA, Perlmutter JS, Parsian A, Guttman M, Nicholson G, Xu G, Wilk JB, Saint-Hilaire MH, DeStefano AL, Prakash R, Williamson S, Suchowersky O, Labelle N, Growdon JH, Singer C, Watts RL, Goldwurm S, Pezzoli G, Baker KB, Pramstaller PP, Burn DJ, Chinnery PF, Sherman S, Vieregge P, Litvan I, Gillis T, MacDonald ME, Myers RH, Gusella JF. Influence of heterozygosity for parkin mutation on onset age in familial Parkinson disease: the GenePD study. Arch Neurol 2006;63:826-32.

95. Kay DM, Moran D, Moses L, Poorkaj P, Zabetian CP, Nutt J, Factor SA, Yu CE, Montimurro JS, Keefe RG, Schellenberg GD, Payami $\mathrm{H}$. Heterozygous parkin point mutations are as common in control subjects as in Parkinson's patients. Ann Neurol 2007;61:47-54.

96. Chien HF, Rohé CF, Costa MD, Breedveld GJ, Oostra BA, Barbosa ER, Bonifati V. Early-onset Parkinson's disease caused by a novel parkin mutation in a genetic isolate from north-eastern Brazil. Neurogenetics 2006; 7:13-9.

97. Periquet M, Lücking C, Vaughan J, Bonifati V, Dürr A, De Michele G, Horstink M, Farrer M, Illarioshkin SN, Pollak P, Borg M, Brefel-Courbon C, Denefle P, Meco G, Gasser T, Breteler MM, Wood N, Agid Y, Brice A; French Parkinson's Disease Genetics Study Group. The European Consortium on Genetic Susceptibility in Parkinson's Disease. Origin of the mutations in the parkin gene in Europe: exon rearrangements are independent recurrent events, whereas point mutations may result from founder effects. Am J Hum Genet 2001;68:617-26.

98. Hedrich K, Kann M, Lanthaler AJ, Dalski A, Eskelson C, Landt O, Schwinger E, Vieregge P, Lang AE, Breakefield XO, Ozelius LJ, Pramstaller PP, Klein $\mathrm{C}$. The importance of gene dosage studies: mutational analysis of the parkin gene in early-onset parkinsonism. Hum Mol Genet 2001;10:1649-56.

99. Pankratz N, Kissell DK, Pauciulo MW, Halter CA, Rudolph A, Pfeiffer RF, Marder KS, Foroud T, Nichols WC; Parkinson Study Group-PROGENI Investigators. Parkin dosage mutations have 
greater pathogenicity in familial PD than simple sequence mutations. Neurology 2009;73:279-86.

100. Valente EM, Abou-Sleiman PM, Caputo V, Muqit MM, Harvey K, Gispert S, Ali Z, Del Turco D, Bentivoglio AR, Healy DG, Albanese A, Nussbaum R, González-Maldonado R, Deller T, Salvi S, Cortelli P, Gilks WP, Latchman DS, Harvey RJ, Dallapiccola B, Auburger G, Wood NW. Hereditary early-onset Parkinson's disease caused by mutations in PINK1. Science 2004;304:1158-60.

101. Tan EK, Yew K, Chua E, Puvan K, Shen H, Lee E, Puong KY, Zhao Y, Pavanni R, Wong MC, Jamora D, de Silva D, Moe KT, Woon FP, Yuen Y, Tan L. PINK1 mutations in sporadic early-onset Parkinson's disease. Mov Disord 2006;21:789-93.

102. Marongiu R, Ferraris A, Ialongo T, Michiorri S, Soleti F, Ferrari F, Elia AE, Ghezzi D, Albanese A, Altavista MC, Antonini A, Barone P, Brusa L, Cortelli P, Martinelli P, Pellecchia MT, Pezzoli G, Scaglione C, Stanzione P, Tinazzi M, Zecchinelli A, Zeviani M, Cassetta E, Garavaglia B, Dallapiccola B, Bentivoglio AR, Valente EM; Italian PD Study Group. PINK1 heterozygous rare variants: prevalence, significance and phenotypic spectrum. Hum Mutat 2008;29:565.

103. Plun-Favreau H, Hardy J. PINK1 in mitochondrial function. Proc Natl Acad Sci U S A 2008;105:11041-2.

104. Valente EM, Abou-Sleiman PM, Caputo V, Muqit MM, Harvey K, Gispert S, Ali Z, Del Turco D, Bentivoglio AR, Healy DG, Albanese A, Nussbaum R, González-Maldonado R, Deller T, Salvi S, Cortelli P, Gilks WP, Latchman DS, Harvey RJ, Dallapiccola B, Auburger G, Wood NW. Hereditary early-onset Parkinson's disease caused by mutations in PINK1. Science 2004;304:1158-60.

105. Bonifati V, Rohé CF, Breedveld GJ, Fabrizio E, De Mari M, Tassorelli C, Tavella A, Marconi R, Nicholl DJ, Chien HF, Fincati E, Abbruzzese G, Marini P, De Gaetano A, Horstink MW, Maat-Kievit JA, Sampaio C, Antonini A, Stocchi F, Montagna P, Toni V, Guidi M, Dalla Libera A, Tinazzi M, De Pandis F, Fabbrini G, Goldwurm S, de Klein A, Barbosa E, Lopiano L, Martignoni E, Lamberti P, Vanacore N, Meco G, Oostra BA; Italian Parkinson Genetics Network. Early-onset parkinsonism associated with PINK1 mutations: frequency, genotypes, and phenotypes. Neurology 2005;65:87-95.

106. Ibáñez P, Lesage S, Lohmann E, Thobois S, De Michele G, Borg M, Agid Y, Dürr A, Brice A; French Parkinson's Disease Genetics Study Group. Mutational analysis of the PINK1 gene in early-onset parkinsonism in Europe and North Africa. Brain 2006;129:686-94.

107. Nagakubo D, Taira T, Kitaura H, Ikeda M, Tamai K, Iguchi-Ariga SM, Ariga H. DJ-1, a novel oncogene which transforms mouse NIH3T3 cells in cooperation with ras. Biochem Biophys Res Commun 1997;231:509-13.

108. Kim RH, Peters M, Jang Y, Shi W, Pintilie M, Fletcher GC, DeLuca C, Liepa J, Zhou L, Snow B, Binari RC, Manoukian AS, Bray MR, Liu FF, Tsao MS, Mak TW. DJ-1, a novel regulator of the tumor suppressor PTEN. Cancer Cell 2005;7:263-73.

109. Bonifati V, Rizzu P, van Baren MJ, Schaap O, Breedveld GJ, Krieger E, Dekker MC, Squitieri F, Ibanez P, Joosse M, van Dongen JW, Vanacore N, van Swieten JC, Brice A, Meco G, van Duijn CM, Oostra BA, Heutink P. Mutations in the DJ-1 gene associated with autosomal recessive early-onset parkinsonism. Science 2003;299:256-9.

110. Abou-Sleiman PM, Healy DG, Wood NW. Causes of Parkinson's disease: genetics of DJ-1. Cell Tissue Res 2004;318:185-8.

111. Lev N, Ickowicz D, Melamed E, Offen D. Oxidative insults induce DJ-1 upregulation and redistribution: implications for neuroprotection. Neurotoxicology 2008;29:397-405.

112. Bonifati V, Oostra BA, Heutink P. Linking DJ-1 to neurodegeneration offers novel insights for understanding the pathogenesis of Parkinson's disease. J Mol Med (Berl) 2004;82:163-74.

113. Tomiyama H, Li Y, Yoshino H, Mizuno Y, Kubo S, Toda T, Hattori N. Mutation analysis for DJ-1 in sporadic and familial parkinsonism: screening strategy in parkinsonism. Neurosci Lett 2009;455:159-61.

114. Liu Y, Fallon L, Lashuel HA, Liu Z, Lansbury PT Jr. The UCH-L1 gene encodes two opposing enzymatic activities that affect alpha-synuclein degradation and Parkinson's disease susceptibility.
Cell 2002;111:209-18

115. Leroy E, Boyer R, Auburger G, Leube B, Ulm G, Mezey E, Harta G, Brownstein MJ, Jonnalagada S, Chernova T, Dehejia A, Lavedan C, Gasser T, Steinbach PJ, Wilkinson KD, Polymeropoulos MH. The ubiquitin pathway in Parkinson's disease. Nature 1998;395:451-2.

116. Maraganore DM, Lesnick TG, Elbaz A, Chartier-Harlin MC, Gasser T, Krüger R, Hattori N, Mellick GD, Quattrone A, Satoh J, Toda T, Wang J, Ioannidis JP, de Andrade M, Rocca WA; UCHL1 Global Genetics Consortium. UCHL1 is a Parkinson's disease susceptibility gene. Ann Neurol 2004;55:512-21.

117. Healy DG, Abou-Sleiman PM, Casas JP, Ahmadi KR, Lynch T, Gandhi S, Muqit MM, Foltynie T, Barker R, Bhatia KP, Quinn NP, Lees AJ, Gibson JM, Holton JL, Revesz T, Goldstein DB, Wood NW. UCHL-1 is not a Parkinson's disease susceptibility gene. Ann Neurol 2006;59:627-33.

118. Gray CW, Ward RV, Karran E, Turconi S, Rowles A, Viglienghi D, Southan C, Barton A, Fantom KG, West A, Savopoulos J, Hassan NJ, Clinkenbeard H, Hanning C, Amegadzie B, Davis JB, Dingwall C, Livi GP, Creasy CL. Characterization of human HtrA2, a novel serine protease involved in the mammalian cellular stress response. Eur J Biochem 2000;267:5699-710.

119. Park HJ, Seong YM, Choi JY, Kang S, Rhim H. Alzheimer's disease-associated amyloid beta interacts with the human serine protease HtrA2/Omi. Neurosci Lett 2004;357:63-7.

120. Martins LM, Morrison A, Klupsch K, Fedele V, Moisoi N, Teismann P, Abuin A, Grau E, Geppert M, Livi GP, Creasy CL, Martin A, Hargreaves I, Heales SJ, Okada H, Brandner S, Schulz JB, Mak T, Downward J. Neuroprotective role of the Reaper-related serine protease HtrA2/Omi revealed by targeted deletion in mice. Mol Cell Biol 2004;24:9848-62.

121. Strauss KM, Martins LM, Plun-Favreau H, Marx FP, Kautzmann S, Berg D, Gasser T, Wszolek Z, Müller T, Bornemann A, Wolburg H, Downward J, Riess O, Schulz JB, Krüger R. Loss of function mutations in the gene encoding Omi/HtrA2 in Parkinson's disease. Hum Mol Genet 2005;14:2099-111.

122. Simón-Sánchez J, Singleton AB. Sequencing analysis of OMI/HTRA2 shows previously reported pathogenic mutations in neurologically normal controls. Hum Mol Genet 2008;17:1988-93.

123. Bogaerts V, Nuytemans K, Reumers J, Pals P, Engelborghs S, Pickut B, Corsmit E, Peeters K, Schymkowitz J, De Deyn PP, Cras P, Rousseau F, Theuns J, Van Broeckhoven C. Genetic variability in the mitochondrial serine protease HTRA2 contributes to risk for Parkinson disease. Hum Mutat 2008;29:832-40.

124. Krüger R, Sharma M, Riess O, Gasser T, Van Broeckhoven C Theuns J, Aasly J, Annesi G, Bentivoglio AR, Brice A, Djarmati A, Elbaz A, Farrer M, Ferrarese C, Gibson JM, Hadjigeorgiou GM, Hattori N, Ioannidis JP, Jasinska-Myga B, Klein C, Lambert JC, Lesage S, Lin JJ, Lynch T, Mellick GD, de Nigris F, Opala G, Prigione A, Quattrone A, Ross OA, Satake W, Silburn PA, Tan EK, Toda T, Tomiyama H, Wirdefeldt K, Wszolek Z, Xiromerisiou G, Maraganore DM; Genetic Epidemiology of Parkinson's disease consortium. A large-scale genetic association study to evaluate the contribution of Omi/HtrA2 (PARK13) to Parkinson's disease. Neurobiol Aging 2011;32:548.e9-18.

125. Pankratz N, Nichols WC, Uniacke SK, Halter C, Rudolph A, Shults C Conneally PM, Foroud T; Parkinson Study Group. Genome screen to identify susceptibility genes for Parkinson disease in a sample without parkin mutations. Am J Hum Genet 2002;71:124-35.

126. Pankratz N, Nichols WC, Uniacke SK, Halter C, Rudolph A, Shults C, Conneally PM, Foroud T; Parkinson Study Group. Significant linkage of Parkinson disease to chromosome 2q36-37. Am J Hum Genet 2003;72:1053-7.

127. Lautier C, Goldwurm S, Dürr A, Giovannone B, Tsiaras WG Pezzoli G, Brice A, Smith RJ. Mutations in the GIGYF2 (TNRC15) gene at the PARK11 locus in familial Parkinson disease. Am J Hum Genet 2008;82:822-33.

128. Bras J, Simón-Sánchez J, Federoff M, Morgadinho A, Januario C, Ribeiro M, Cunha L, Oliveira C, Singleton AB. Lack of replication of association between GIGYF2 variants and Parkinson disease. 
Hum Mol Genet 2009;18:341-6.

129. Tan EK, Schapira AH. Summary of GIGYF2 studies in Parkinson's disease: the burden of proof. Eur J Neurol 2010;17:175-6.

130. Vilariño-Güell C, Wider C, Ross OA, Dachsel JC, Kachergus JM, Lincoln SJ, Soto-Ortolaza AI, Cobb SA, Wilhoite GJ, Bacon JA, Behrouz B, Melrose HL, Hentati E, Puschmann A, Evans DM, Conibear E, Wasserman WW, Aasly JO, Burkhard PR, Djaldetti R, Ghika J, Hentati F, Krygowska-Wajs A, Lynch T, Melamed E, Rajput A, Rajput AH, Solida A, Wu RM, Uitti RJ, Wszolek ZK, Vingerhoets F, Farrer MJ. VPS35 mutations in Parkinson disease. Am J Hum Genet 2011;89:162-7.

131. Zimprich A, Benet-Pagès A, Struhal W, Graf E, Eck SH, Offman MN, Haubenberger D, Spielberger S, Schulte EC, Lichtner P, Rossle SC, Klopp N, Wolf E, Seppi K, Pirker W, Presslauer S, Mollenhauer B, Katzenschlager R, Foki T, Hotzy C, Reinthaler E, Harutyunyan A, Kralovics R, Peters A, Zimprich F, Brücke T, Poewe W, Auff E, Trenkwalder C, Rost B, Ransmayr G, Winkelmann J, Meitinger T, Strom TM. A mutation in VPS35, encoding a subunit of the retromer complex, causes late-onset Parkinson disease. Am J Hum Genet 2011;89:168-75.

132. Guo JF, Sun QY, Lv ZY, Yu RL, Li K, Zhang YH, Zhang YH, Tian JY, Xia K, Yan XX, Tang BS. VPS35 gene variants are not associated with Parkinson's disease in the mainland Chinese population. Parkinsonism Relat Disord 2012;18:983-5.

133. Chen Y, Chen K, Song W, Chen X, Cao B, Huang R, Zhao B, Guo X, Burgunder J, Li J, Shang HF. VPS35 Asp620Asn and EIF4G1 Arg1205His mutations are rare in Parkinson disease from southwest China. Neurobiol Aging 2013;34:1709.e7-8.

134. Ando M, Funayama M, Li Y, Kashihara K, Murakami Y, Ishizu N, Toyoda C, Noguchi K, Hashimoto T, Nakano N, Sasaki R, Kokubo Y, Kuzuhara S, Ogaki K, Yamashita C, Yoshino H, Hatano T, Tomiyama H, Hattori N. VPS35 mutation in Japanese patients with typical Parkinson's disease. Mov Disord 2012;27:1413-7.

135. Morgan NV, Westaway SK, Morton JE, Gregory A, Gissen P, Sonek S, Cangul H, Coryell J, Canham N, Nardocci N, Zorzi G, Pasha S, Rodriguez D, Desguerre I, Mubaidin A, Bertini E, Trembath RC, Simonati A, Schanen C, Johnson CA, Levinson B, Woods CG, Wilmot B, Kramer P, Gitschier J, Maher ER, Hayflick SJ. PLA2G6, encoding a phospholipase $\mathrm{A} 2$, is mutated in neurodegenerative disorders with high brain iron. Nat Genet 2006;38:752-4

136. Paisan-Ruiz C, Bhatia KP, Li A, Hernandez D, Davis M, Wood NW, Hardy J, Houlden H, Singleton A, Schneider SA. Characterization of PLA2G6 as a locus for dystonia-parkinsonism. Ann Neurol 2009;65:19-23.

137. Tomiyama H, Yoshino H, Ogaki K, Li L, Yamashita C, Li Y, Funayama M, Sasaki R, Kokubo Y, Kuzuhara S, Hattori N. PLA2G6 variant in Parkinson's disease. J Hum Genet 2011;56:401-3.

138. Lv Z, Guo J, Sun Q, Li K, Yu R, Tian J, Yan X, Tang B. Association between PLA2G6 gene polymorphisms and Parkinson's disease in the Chinese Han population. Parkinsonism Relat Disord 2012;18:641-4

139. Chartier-Harlin MC, Dachsel JC, Vilariño-Güell C, Lincoln SJ, Leprêtre F, Hulihan MM, Kachergus J, Milnerwood AJ, Tapia L, Song MS, Le Rhun E, Mutez E, Larvor L, Duflot A, Vanbesien-Mailliot C, Kreisler A, Ross OA, Nishioka K, Soto-Ortolaza AI, Cobb SA, Melrose HL, Behrouz B, Keeling BH,
Bacon JA, Hentati E, Williams L, Yanagiya A, Sonenberg N, Lockhart PJ, Zubair AC, Uitti RJ, Aasly JO, Krygowska-Wajs A, Opala G, Wszolek ZK, Frigerio R, Maraganore DM, Gosal D, Lynch T, Hutchinson M, Bentivoglio AR, Valente EM, Nichols WC, Pankratz N, Foroud T, Gibson RA, Hentati F, Dickson DW, Destée A, Farrer MJ. Translation initiator EIF4G1 mutations in familial Parkinson disease. Am J Hum Genet 2011;89:398-406.

140. Sudhaman S, Behari M, Govindappa ST, Muthane UB, Juyal RC, Thelma BK. VPS35 and EIF4G1 mutations are rare in Parkinson's disease among Indians. Neurobiol Aging 2013;34:2442.e1-3.

141. Nishioka K, Funayama M, Vilariño-Güell C, Ogaki K, Li Y, Sasaki R, Kokubo Y, Kuzuhara S, Kachergus JM, Cobb SA, Takahashi H, Mizuno Y, Farrer MJ, Ross OA, Hattori N. EIF4G1 gene mutations are not a common cause of Parkinson's disease in the Japanese population. Parkinsonism Relat Disord 2014;20:659-61.

142. Saad M, Lesage S, Saint-Pierre A, Corvol JC, Zelenika D, Lambert JC, Vidailhet M, Mellick GD, Lohmann E, Durif F, Pollak P, Damier P, Tison F, Silburn PA, Tzourio C, Forlani S, Loriot MA, Giroud M, Helmer C, Portet F, Amouyel P, Lathrop M, Elbaz A, Durr A, Martinez M, Brice A; French Parkinson's Disease Genetics Study Group. Genome-wide association study confirms BST1 and suggests a locus on 12q24 as the risk loci for Parkinson's disease in the European population. Hum Mol Genet 2011;20:615-27.

143. Wang C, Feng X, Xie S, Gu Z, Chan P. Exonic sequencing revealed no causative mutation in the BST1 gene in patients with Parkinson's disease. Neurobiol Aging 2013;34:2695.e9-10.

144. Harbo HF, Finsterer J, Baets J, Van Broeckhoven C, Di Donato S, Fontaine $\mathrm{B}$, De Jonghe $\mathrm{P}$, Lossos $\mathrm{A}$, Lynch $\mathrm{T}$, Mariotti $\mathrm{C}$, Schöls L, Spinazzola A, Szolnoki Z, Tabrizi SJ, Tallaksen C, Zeviani M, Burgunder JM, Gasser T; EFNS. EFNS guidelines on the molecular diagnosis of neurogenetic disorders: general issues, Huntington's disease, Parkinson's disease and dystonias. Eur $J$ Neurol 2009;16:777-85.

145. Marek K, Jennings D, Tamagnan G, Seibyl J. Biomarkers for Parkinson's [corrected] disease: tools to assess Parkinson's disease onset and progression. Ann Neurol 2008;64 Suppl 2:S111-21.

146. Dickson DW, Braak H, Duda JE, Duyckaerts C, Gasser T, Halliday GM, Hardy J, Leverenz JB, Del Tredici K, Wszolek ZK, Litvan I. Neuropathological assessment of Parkinson's disease: refining the diagnostic criteria. Lancet Neurol 2009;8:1150-7.

147. Forman MS, Lee VM, Trojanowski JQ. Nosology of Parkinson's disease: looking for the way out of a quagmire. Neuron 2005; 47:479-82.

148. Wang C, Cai Y, Gu Z, Ma J, Zheng Z, Tang BS, Xu Y, Zhou Y, Feng T, Wang T, Chen SD, Chan P; Chinese Parkinson Study Group. Clinical profiles of Parkinson's disease associated with common leucine-rich repeat kinase 2 and glucocerebrosidase genetic variants in Chinese individuals. Neurobiol Aging 2014;35:725.e1-6.

Cite this article as: Wang CD, Chan P. Clinicogenetics of Parkinson's disease: a drawing but not completed picture. Neuroimmunol Neuroinflammation 2014;1(3):115-26.

Source of Support: Nil. Conflict of Interest: No.

Received: 15-07-2014; Accepted: 05-09-2014 